\title{
Simulating dam-breach flood scenarios of the Tangjiashan landslide dam induced by the Wenchuan Earthquake
}

\author{
X. Fan ${ }^{1,2}$, C. X. Tang ${ }^{2}$, C. J. van Westen ${ }^{2}$, and D. Alkema ${ }^{2}$ \\ ${ }^{1}$ The State Key Laboratory of Geohazards Prevention and Geoenvironment Protection (Chengdu University of Technology), \\ Chengdu, Sichuan, China \\ ${ }^{2}$ Faculty of Geo-Information Science and Earth Observation (ITC), University of Twente, 7500 AE, Enschede, P.O. Box 217, \\ The Netherlands
}

Correspondence to: X. Fan (fan21676@itc.nl)

Received: 3 June 2012 - Revised: 8 August 2012 - Accepted: 9 August 2012 - Published: 2 October 2012

\begin{abstract}
Floods from failures of landslide dams can pose a hazard to people and property downstream, which have to be rapidly assessed and mitigated in order to reduce the potential risk. The Tangjiashan landslide dam induced by the $M_{\mathrm{w}}=7.92008$ Wenchuan earthquake had impounded the largest lake in the earthquake affected area with an estimated volume of $3 \times 10^{8} \mathrm{~m}^{3}$, and the potential catastrophic dam breach posed a serious threat to more than 2.5 million people in downstream towns and Mianyang city, located $85 \mathrm{~km}$ downstream. Chinese authorities had to evacuate parts of the city until the Tangjiashan landslide dam was artificially breached by a spillway, and the lake was drained. We propose an integrated approach to simulate the dam-breach floods for a number of possible scenarios, to evaluate the severity of the threat to Mianyang city. Firstly, the physicallybased BREACH model was applied to predict the flood hydrographs at the dam location, which were calibrated with observational data of the flood resulting from the artificial breaching. The output hydrographs from this model were inputted into the 1-D-2-D SOBEK hydrodynamic model to simulate the spatial variations in flood parameters. The simulated flood hydrograph, peak discharge and peak arrival time at the downstream towns fit the observations. Thus this approach is capable of providing reliable predictions for the decision makers to determine the mitigation plans. The sensitivity analysis of the BREACH model input parameters reveals that the average grain size, the unit weight and porosity of the dam materials are the most sensitive parameters. The variability of the dam material properties causes a large uncertainty in the estimation of the peak flood discharge and peak arrival time, but has little influence on the flood inundation
\end{abstract}

area and flood depth downstream. The effect of cascading breaches of smaller dams downstream of the Tangjiashan dam was insignificant, due to their rather small volumes, which were only $2 \%$ of the volume of the Tangjiashan lake. The construction of the spillway was proven to have played a crucial role in reducing the dam-breach flood, because all the other natural breach scenarios would have caused the flooding of the downstream towns and parts of Mianyang city. However, in retrospect improvements on the spillway design and the evacuation planning would have been possible. The dam-break flood risk will be better controlled by reducing the spillway channel gradient and the porosity of the coating of the channel bottom. The experience and lessons we learned from the Tangjiashan case will contribute to improving the hazard mitigation and risk management planning of similar events in future.

\section{Introduction}

Natural damming of rivers by mass movements are very common and potentially dangerous phenomena (Costa and Schuster, 1988; Evans et al., 2011), which have been documented all over the world, e.g. in Japan (Swanson et al., 1986), Canada (Clague and Evans, 1994), China (Chai et al., 1995), the northern Apennines in Italy (Casagli and Ermini, 1999) and New Zealand (Korup, 2005). Hazards and risks resulting from landslide dams have been reported in many historic accounts of catastrophic floods from natural dam failures. The 27 largest floods of the Quaternary period with discharges greater than $100000 \mathrm{~m}^{3} \mathrm{~s}^{-1}$ 
were listed by O'Connor and Costa (2004), most of which were caused by breaches of glacier or landslide dams. The largest flood in recorded history was caused by the failure of the earthquake-induced Raikhot landslide dam in 1841 on the Indus River in Pakistan, which has an estimated peak discharge of $\sim 540000 \mathrm{~m}^{3} \mathrm{~s}^{-1}$ (Mason, 1929; Shroder Jr., 1998). Schneider (2009) described the largest landslide triggered by the Kashmir earthquake $\left(M_{\mathrm{w}}=7.6\right.$, 2005) in Pakistan, which formed a natural dam impounding two lakes in the Karli river. Some other representative cases were studied by Alexander (1988), Hewitt (1998), Cruden and Miller (2002), Dunning et al. (2006), Gupta and Sah (2008) and Duman (2009). On overview of research work on landslide dams was made by Korup (2002) and Evans et al. (2011).

Many records of large landslide dams and catastrophic outburst floods are known in China. On 1 June 1786, a $M=7.8$ earthquake in the Kangding-Luding area triggered a large $\left(>10^{6} \mathrm{~m}^{3}\right)$ landslide dam that blocked the Dadu River. Ten days later, the dam breached resulting in catastrophic downstream flooding and 100000 fatalities (Dai et al., 2005). Another examples is the sudden breach of three dams (Dahaizi, Xiaohaizi, and Deixi) induced by the Diexi earthquake causing a tragic flood that affected settlements along a downstream distance of $250 \mathrm{~km}$, killing more than 2500 people (Chai et al., 2000). Of all the recorded cases, the largest dam was formed by the Yigong landslide $\left(\sim 3 \times 10^{8} \mathrm{~m}^{3}\right)$ on 9 April 2000 in Tibet, which breached two months later and caused a flash flood with a peak discharge of $120000 \mathrm{~m}^{3} \mathrm{~s}^{-1}$, resulting in 30 fatalities and over 100 people missing (Shang et al., 2003; Xu et al., 2012).

The Tangjiashan landslide dam induced by the devastating 2008 Wenchuan earthquake $\left(M_{\mathrm{w}}=7.9\right)$ in China, highlighted the importance of the dam-breach flooding problem. This dam was the most dangerous one out of the $>800$ coseismic landslide dams mapped by Fan et al. (2012a, b), which had impounded the largest barrier lake with an estimated volume of $3 \times 10^{8} \mathrm{~m}^{3}$, threatening more than 2.5 million people downstream. Chinese authorities decided to evacuate parts of the city until the Tangjiashan landslide dam was artificially breached by a spillway, and the lake was drained (Liu et al., 2009).

For emergency mitigation planning related to potential dam-break floods, the key issues are (1) assessing the dam stability; (2) evaluating the potential dam breach process and mechanism; and (3) predicting the dam-break flood parameters, including the probable peak discharge, depth, velocity, duration and the affected area.

The stability assessment of landslide dams has been an important research theme for a long time. Recently, a geomorphic approach is widely used to correlate the dam and the impounded lake geomorphic features with the landslide dam's stability (Ermini and Casagli, 2003; Dong et al., 2009). Using this approach Cui et al. (2010) concluded that the Tangjiashan dam was unstable. The limitation of this method is that it ignores the dam structure and geotechnical properties of the dam materials (Dunning et al., 2005).

Concerning the dam breach process, Walder and O'Connor (1997) concluded that it was still poorly understood, since it involves a variety of processes, including sediment entrainment from the breach floor, the gravitational collapse of breach sides and the downstream dam face. In the Tangjiashan case, the availability of detailed field data and laboratory-tested geotechnical parameters allow us to use a physically-based model to simulate the dam breach process, predicting the dam-breach flood hydrograph, the failure time and the ultimate breach geometry.

Regarding the dam-break flood modelling, the peak discharge can be predicted by both empirical and numerical simulation methods. The empirical method relies on regression relations between the peak discharge and other parameters, such as the impounded lake volume, depth, and area (Evans, 1986; Costa and Schuster, 1988; see Peng and Zhang, 2012 for an overview). The numerical method includes both a physically based model, e.g. the US National Weather Service BREACH Model (Fread, 1991) and Chang and Zhang (2010) as well as a GIS-based hydraulic model (Li et al., 2011), which can also predict other flood characteristics (flood routing, depth, velocity, duration and the affected area). The empirical model is simple to apply, compared to the numerical model which requires detailed parameters, but it provides less accurate results.

The previous studies on the Tangjiashan landslide dam are mainly concentrated on describing the emergency mitigation works and on the estimation of the dam-break flood using empirical methods (Liu et al., 2009; Xu et al., 2009; Cui et al., 2010) as well as on the prediction of the outburst flood hydrograph using physical models (Wang et al., 2008; Dai et al., 2010). However, there is little work on 2-D hydraulic modelling of the dam-breach flood with consideration of different scenarios, neither on the calibration of the model and on the cascading breach of several smaller downstream dams. To fill these gaps, the physically-based BREACH model and the GIS-based hydraulic SOBEK 1-D-2-D model are integrated in this study to facilitate the dam-break flood modelling of the Tangjiashan dam. This study aims to model the dam-break floods of possible scenarios up to Mianyang city, based on our best understanding of the dam breach process.

\section{Study area}

\subsection{Hydrologic and geological setting}

The Tangjiashan landslide dam is located at $31.84^{\circ} \mathrm{N}$, $104.43^{\circ} \mathrm{E}, \sim 5 \mathrm{~km}$ upstream of the town of Beichuan, which was completely devastated by the Wenchuan earthquake and the large co-seismic landslides, and has not been reconstructed. The landslide blocked the Tongkou river (also called Jianjiang) with an upstream catchment area of $3,550 \mathrm{~km}^{2}$ 
(Fig. 1). The river is $100-130 \mathrm{~m}$ wide and $0.5-4 \mathrm{~m}$ deep, having an asymmetrical $\mathrm{V}$-shaped cross-section with right and left valley-side slope gradient of $\sim 45^{\circ}$ and $25^{\circ}$, respectively. The Tongkou river is mainly supplied by rainfall, with a mean annual precipitation rate of $1287.5 \mathrm{~mm}$. The recorded maximum daily precipitation is $323.4 \mathrm{~mm}$. According to the record from the Beichuan hydraulic station, the average annual discharge of the Tongkou river is $81 \mathrm{~m}^{3} \mathrm{~s}^{-1}$, and increases to $167 \mathrm{~m}^{3} \mathrm{~s}^{-1}$ during the monsoon season which lasts from May to October. The discharge before the dam breached was recorded as $90 \mathrm{~m}^{3} \mathrm{~s}^{-1}$ (Liu et al., 2009). Historical flood records indicate that most of floods occurred in June to September due to extreme rainstorms, with the highest frequency in July and August. In the past $100 \mathrm{yr}$, the largest floods happened in 1902 and 1934 with peak discharges of $6720 \mathrm{~m}^{3} \mathrm{~s}^{-1}$ and $5750 \mathrm{~m}^{3} \mathrm{~s}^{-1}$, respectively. Table 1 shows the peak discharges of floods with different return periods.

The Tangjiashan landslide dam was formed by a rock slide in fragmented bedrock composed of siltstone, siliceous rocks and mudstone of the Qingping Group, from the lower Cambrian (Figs. 2 and 3, modified based on Xu et al., 2009). The bedrock was covered by colluvium (mixed soil and fine rock fragments) with dense vegetation. The landslide is located on the hanging wall of the main fault (Yingxiu-Beichuan fault), only $2 \mathrm{~km}$ away from the surface fault rupture. Due to the strong seismic energy, the steep terrain and the fragile geological structure, the landslide slid down into the river along the steep sliding surface $\left(60^{\circ}\right)$ and even ran up to the opposite slope, forming a $550 \mathrm{~m}$ high scarp (Fig. 2). The dam volume was estimated to be $2.04 \times 10^{7} \mathrm{~m}^{3}$ with a height varying from $82 \mathrm{~m}$ to $124 \mathrm{~m}$ through preliminary field measures (Liu et al., 2009). The dam crest extended approximately $600 \mathrm{~m}$ across the valley and $800 \mathrm{~m}$ along the valley. It had impounded a lake with $2.47 \times 10^{8} \mathrm{~m}^{3}$ of water till 7 June 2008 , and with an estimated maximum capacity of $3 \times 10^{8} \mathrm{~m}^{3}$ (Liu et al., 2009). We generated the post-earthquake DEM with 5-m spatial resolution from the field-measured 2-m interval contours covering the area from the dam site to the Beichuan town (Fig. 4). The dam volume was calculated to be $1.7 \times 10^{7} \mathrm{~m}^{3}$ by comparing the pre- and post- earthquake DEMs. There are also several smaller landslide dams located at the downstream of the Tangjiashan dam (Fig. 4).

The detailed geological survey and boreholes were carried out by Chengdu Hydroelectric Investigation and Design Institute (CHIDI) in China (2008), revealing that the Tangjiashan landslide dam body is complex in its geological structure with four different layers from the top to the bottom (Fig. 3): (1) a 5-15 m thick layer of loose soil $(60 \%)$ and rock fragments $(40 \%)$ with grain sizes $<5 \mathrm{~cm}$, which are easily erodible; (2) a $10-30 \mathrm{~m}$ thick layer of stronglyweathered rock blocks $(6-40 \mathrm{~cm}$ in diameter) and boulders (1-2 m); (3) a 50-67 m thick layer consisting of partly intact rock strata retaining the original structure, which is relatively more densely packed and has lower permeability than

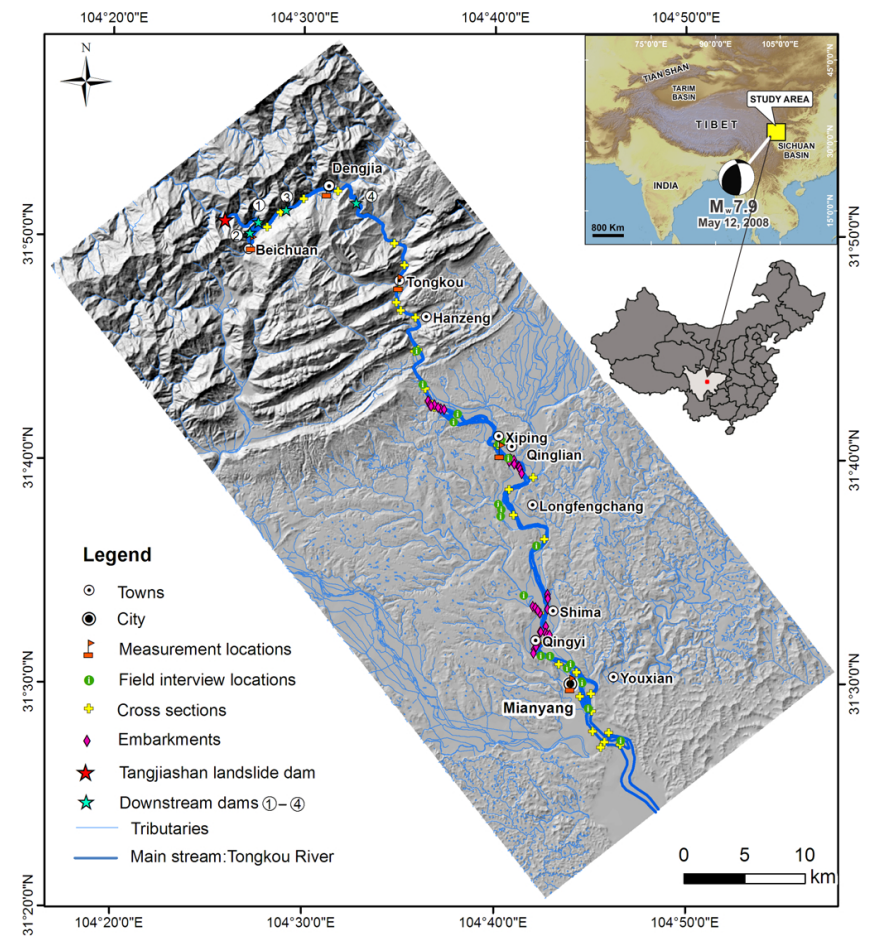

Fig. 1. Location of the Tangjiashan landslide dam and the layout of the field measurements. The measurement location in Beichuan is the same as the Beichuan hydraulic station.

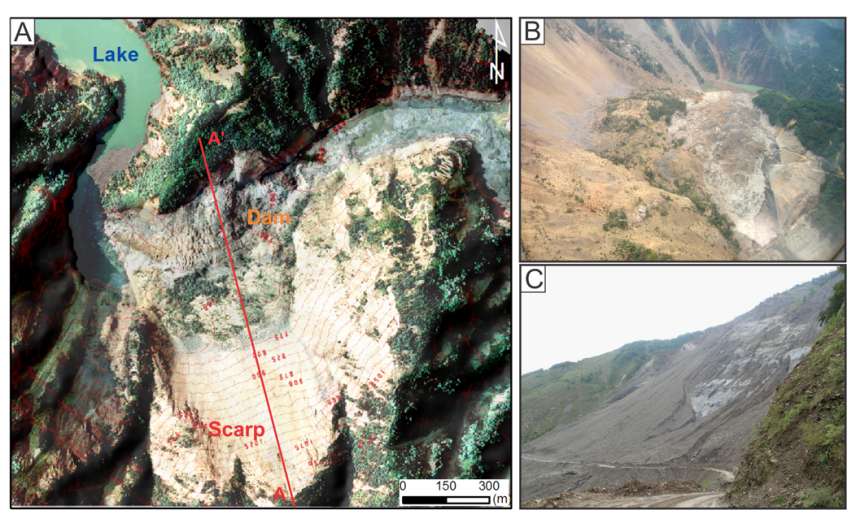

Fig. 2. (A) Aerial photo of the Tangjiashan landslide dam (source: Ministry of Land and Resources); (B) photo of the dam body; (C) photo of the landslide back scarp.

the above two layers; and (4) a 6-15.7 m thick layer of silt, sand and fine gravels mostly from the alluvial deposits on the river bed.

\subsection{Mitigation measures}

The Tangjiashan landslide dam was formed in the monsoon season, thus the high inflow filled the lake rapidly and made the mitigation more urgent. To reduce this risk, the Chinese government carried out several mitigation measures, 
Table 1. Peak Discharge of floods with different return periods calculated from measurements at the Beichuan Hydraulic Station.

\begin{tabular}{lrrrrrrr}
\hline Return period (years) & 2 & 5 & 10 & 20 & 50 & 100 & 200 \\
Peak discharge $\left(\mathrm{m}^{3} \mathrm{~s}^{-1}\right)$ & 1180 & 2190 & 3040 & 3920 & 5120 & 6040 & 6970 \\
\hline
\end{tabular}

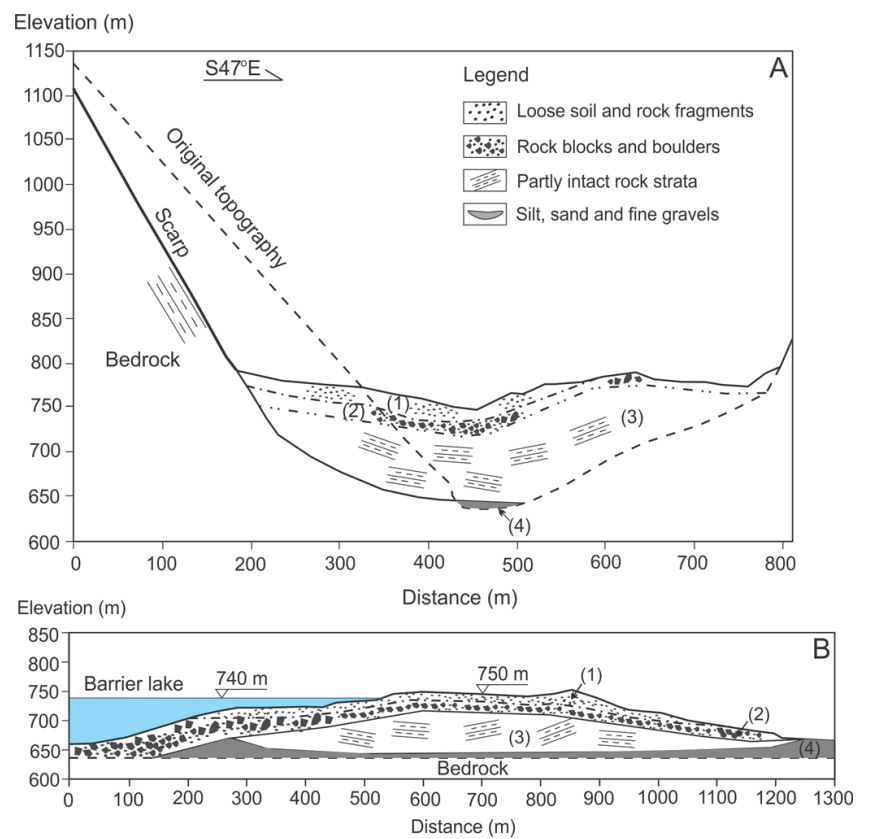

Fig. 3. (A) Geological profile (A-A' in Fig. 2) of the Tangjiashan landslide; (B) Longitudinal cross-section of the dam body along the valley showing four-layered structure, modified based on Chengdu Hydroelectric Investigation and Design Institute (CHIDI) in China (2008) and Xu et al. (2009).

including 24-h monitoring of the lake level and the dam stability situation, construction of a large emergency spillway and evacuation of the people in the possible flooded area. The spillway was designed as a trapezoid cross-section with a slope of $1: 1.5$ on both sides of the channel (Fig. 5a). It was $13 \mathrm{~m}$ wide, up to $9 \mathrm{~m}$ deep, $695 \mathrm{~m}$ long, and designed to be capable to accommodate $1,160 \mathrm{~m}^{3} \mathrm{~s}^{-1}$. The longitudinal channel gradient of the spillway varies from $0.6 \%$ to $24 \%$ from the upper reaches to the lower reaches (Liu et al., 2009). The construction work started on 26 May and was completed on 1 June 2008, lowering the lowest point on the dam crest from $750 \mathrm{~m}$ to $740.7 \mathrm{~m}$. On 7 June when the impounded water level rose to the lowest point on the dam crest, the spillway started to drain the lake. The peak discharge of $6,500 \mathrm{~m}^{3} \mathrm{~s}^{-1}$ appeared at 12:30 h (LT) on 10 June and declined quickly to $79 \mathrm{~m}^{3} \mathrm{~s}^{-1}$ at $8: 45 \mathrm{~h}$ (LT) on 11 June (Fig. 5b). During this period, $1.6 \times 10^{8} \mathrm{~m}^{3}$ water was released and the water level of the lake dropped $\sim 27 \mathrm{~m}$ (Cui et al., 2010). Due to the strong incision and erosion of the two top layers of the dam body, the spillway rapidly enlarged to a width of $100-130 \mathrm{~m}$ and eventually a depth of $40-60 \mathrm{~m}$, and about $5 \times 10^{6} \mathrm{~m}^{3}$ of material was eroded (Liu et al., 2009). Currently, the remaining part of the dam body is enhanced by concrete, still impounding about $8 \times 10^{7} \mathrm{~m}^{3}$ of water (Fig. $5 \mathrm{c}$ and d).

\section{Data and methods}

To simulate the dam-breach flood, we integrated the BREACH model (Fread, 1991) and the SOBEK 1-D-2-D model developed by Deltares (Dhondia and Stelling, 2002). The BREACH model can simulate the outflow hydrograph emanating from a dam and quantify the dam breach process. To calibrate the model, we reconstructed the 2008 event by setting up the spillway as a base scenario. The outputs of the BREACH model for different scenarios were subsequently used in the SOBEK model. The integrated simulation approach is depicted in the flowchart in Fig. 6.

Four scenarios were considered in this study:

Scenarios 1: assuming that the dam would breach naturally without the spillway under the same hydrological condition as the base (calibrated) scenario for the purpose of evaluating the effects of the spillway.

Scenarios 2: the same as Scenario 1, but also considering that the breach of the Tangjiashan dam would cause the cascading breach of the four smaller downstream dams as shown in Figs. 1 and 4.

Scenarios 3: assuming that the dam would breach naturally given a 5-yr return period flood discharge of $2190 \mathrm{~m}^{3} \mathrm{~s}^{-1}$ (see Table 1) as inflow to lake, under a heavy rainstorm situation. The 5-yr return period was selected as it is likely to occur and can provide largely different outputs from other scenarios.

Scenarios 4: assuming the geotechnical parameters of dam material would be the most unfavourable (worst combination), leading to the whole breach of the dam and the completely releasing all the water in the barrier lake, which is the most catastrophic scenario compared to others.

\subsection{The BREACH model and data requirements}

The BREACH model is a physically based mathematical model capable of predicting the breach characteristics and the discharge hydrograph from the breach of a man-made dam or a naturally-formed landslide dam, developed by Fread (1991) at the US National Weather Service. This model is created by coupling the conservation of mass of 


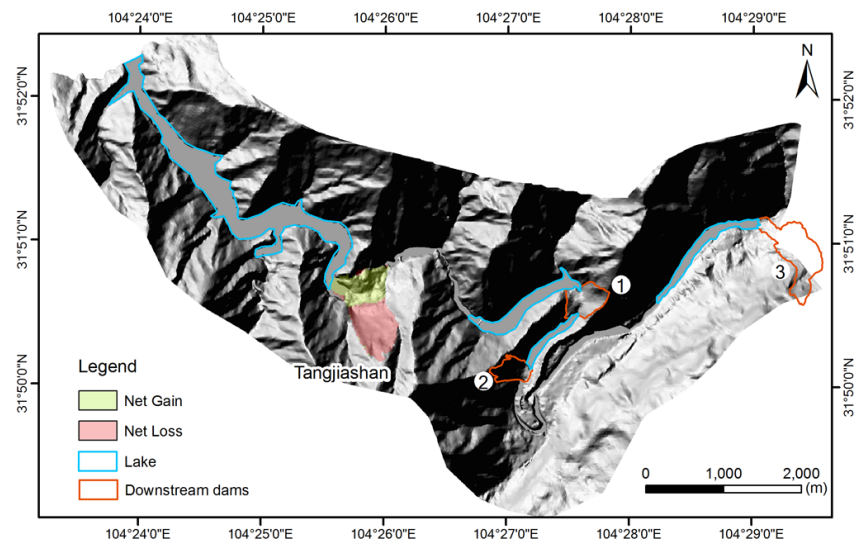

Fig. 4. Post-earthquake 5-m DEM of the Tangjiashan dam and three of the four downstream dams (the fourth one is at the further downstream).

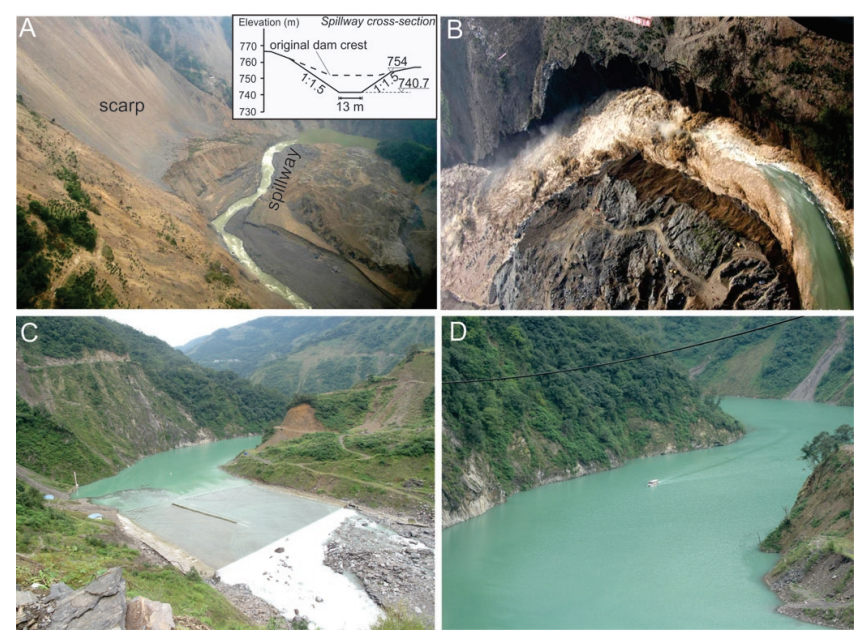

Fig. 5. (A) Helicopter view of the artificial spillway; inset shows the spillway cross-section; (B) releasing impounded water through the spillway, taken on 10 June 2008 when the discharge reached its peak (provided by Liu, N. from Ministry of Water Resources of the People's Republic of China); (C) remaining dam; (D) Remaining lake, (C) and (D) were field photo taken in September 2011.

the reservoir inflow, spillway outflow, and breach outflow with the sediment transport capacity of the unsteady uniform flow along a breach channel formed by erosion. Cencetti et al. (2006) modified the bed-load transport formula (the Meyer-Peter and Muller formula, modified by Smart, 1984) used in the BREACH model to better suit the simulation of channel erosion on landslide dams. The model can deal with breach caused by overtopping and piping, and has been applied to landslide dam breach modelling (Dai et al., 2010; Li et al., 2011). Previous studies (Liu et al., 2009; Cui et al., 2010) have a good agreement that the most probable failure mode of the Tangjiashan dam will be overtopping rather than piping and complete collapse, due to the its geological structure.

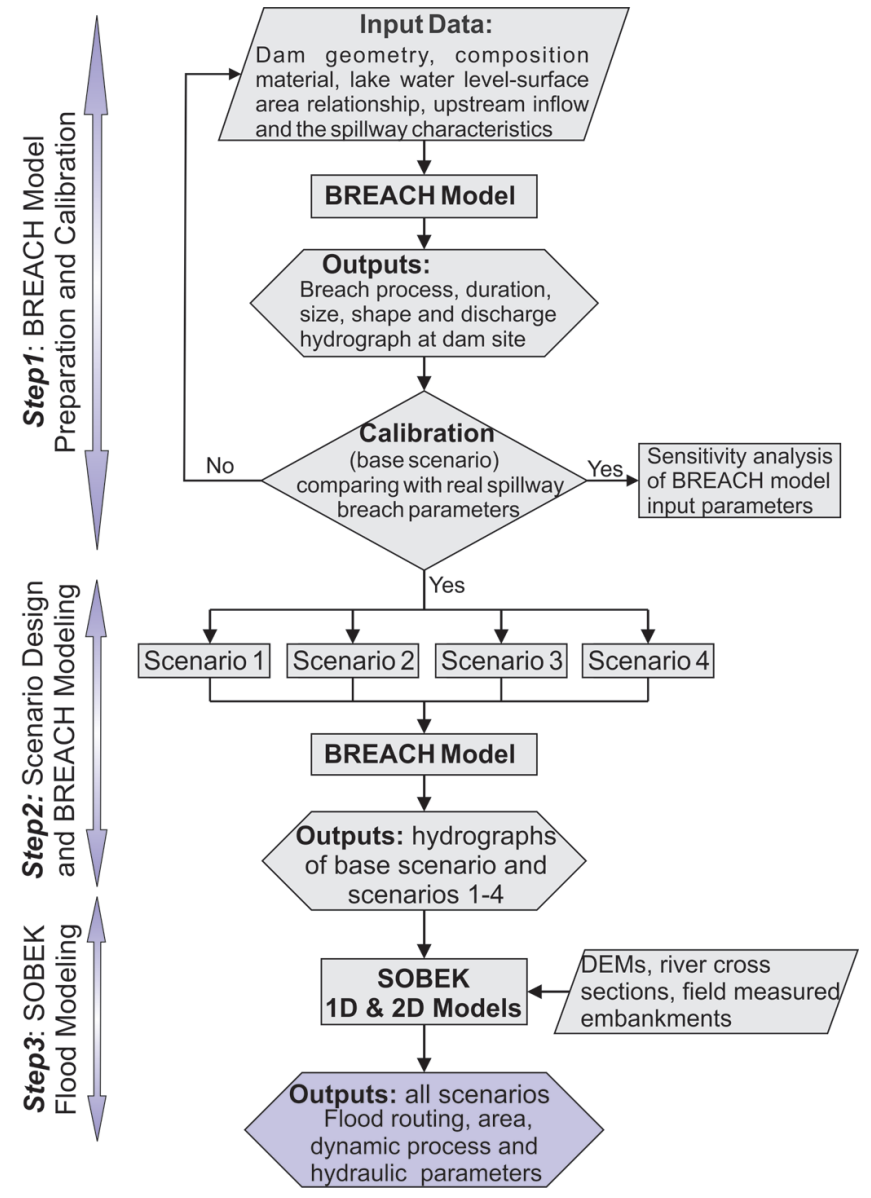

Fig. 6. Flowchart of the integrated simulation approach.

The required input parameters of the BREACH model include the relationship between the water level and the coverage area of the barrier lake, the upstream inflow rate to the barrier lake and the spillway geometry, the dam geometry and material geotechnical properties (Table 2). To obtain a range of material properties of the Tangjiashan dam, 15 samples from dam surface and boreholes were collected and tested in laboratory using various methods (e.g. the quick direct shear test, density test, permeability test and triaxial compression test etc.) by Chengdu Hydroelectric Investigation and Design Institute (CHIDI) in China (2008). Within this range, the most critical combination of the values was determined by the calibrated model (base scenario), which was also used in Scenarios 1-3. For Scenario 4, we have selected the most unfavourable geotechnical properties from the range. A detailed explanation of the physical meaning of the parameters and the model theory can be found in Fread (1991) and Cencetti et al. (2006).

We used the pre-earthquake Digital Elevation Model with a spatial resolution of $25 \mathrm{~m}$ to calculate the lake volume and coverage area for a given lake water level using the OpenSource GIS software ILWIS, which has a specific volume 
Table 2. Input parameters for the BREACH model. A range of the dam material geotechnical properties was measured using laboratory tests shown in the brackets in the base scenario column.

\begin{tabular}{|c|c|c|c|c|}
\hline Parameters & Base scenario & Scenarios 1 and 2 & Scenario 3 & Scenario 4 \\
\hline \multicolumn{5}{|c|}{ Lake parameters } \\
\hline Inflow to lake $\left(\mathrm{m}^{3} \mathrm{~s}^{-1}\right)$ & 90.0 & 90.0 & 2190.0 & 90.0 \\
\hline Lake water level, $H(\mathrm{~m})$ & 740.7 & 750.0 & 750.0 & 750.0 \\
\hline Lake volume, $V\left(\mathrm{~m}^{3}\right)$ & $2.3 \times 10^{8}$ & $3.1 \times 10^{8}$ & $3.1 \times 10^{8}$ & $3.1 \times 10^{8}$ \\
\hline Average depth of lake, $D(\mathrm{~m})$ & 30.6 & 33.7 & 33.7 & 33.7 \\
\hline Lake covered area, $S_{a}\left(\mathrm{~m}^{2}\right)$ & $7.4 \times 10^{6}$ & $9.0 \times 10^{6}$ & $9.0 \times 10^{6}$ & $9.0 \times 10^{6}$ \\
\hline \multicolumn{5}{|l|}{ Dam and spillway geometry } \\
\hline Dam crest elevation, $H_{u}(\mathrm{~m})$ & 750.0 & 750.0 & 750.0 & 750.0 \\
\hline Dam downstream face gradient, $S$ & 0.10 & 0.18 & 0.18 & 0.18 \\
\hline Initial breach bottom elevation, $H_{c}(\mathrm{~m})$ & 740.7 & - & - & - \\
\hline Initial width of breach bottom, $B_{O}(\mathrm{~m})$ & 13.0 & - & - & - \\
\hline Spillway length, $L(\mathrm{~m})$ & 695.0 & - & - & - \\
\hline \multicolumn{5}{|l|}{ Geotechnical properties of dam material } \\
\hline Unit weight, $\rho\left(\mathrm{kg} \mathrm{m}^{-3}\right)$ & $2400(1900-2500)$ & 2400 & 2400 & 1900 \\
\hline Internal friction angle $\phi,\left(^{\circ}\right)$ & $30(24-36)$ & 30 & 30 & 24 \\
\hline Cohesion, $C(\mathrm{kPa})$ & $13(10-15)$ & 13 & 13 & 10 \\
\hline$D_{50}(\mathrm{~m})$ & $1.1(0.4-2.0)$ & 1.1 & 1.1 & 0.4 \\
\hline Porosity, $P_{\text {or }}$ & $0.32(0.28-0.45)$ & 0.32 & 0.32 & 0.45 \\
\hline
\end{tabular}

Note: $D_{50}$ is defined as the grain diameter at which $50 \%$ of dam sediments are finer; porosity, $P_{\text {or }}$ is the ratio of voids to the total volume of a specimen.

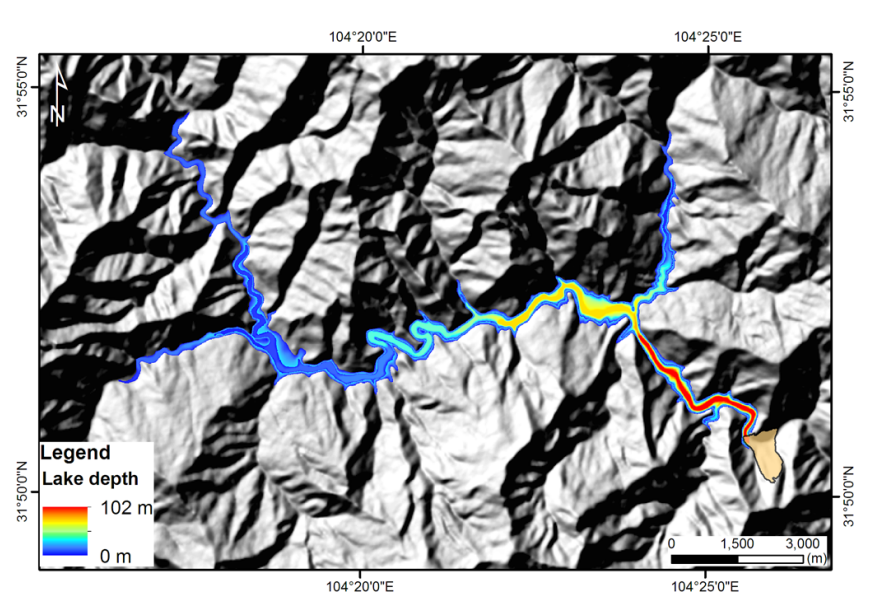

Fig. 7. Variation of the barrier lake depth (the background is the shaded relief map of the pre-earthquake 25-m DEM).

calculation function (Fig. 7). The result is consistent with previous estimations (Liu et al., 2009; Cui et al., 2010), showing that the maximum capacity of the barrier lake is $3.1 \times 10^{8} \mathrm{~m}^{3}$ with the lake water level at $750 \mathrm{~m}$, and about $1.5 \times 10^{8} \mathrm{~m}^{3}$ water was drained by the spillway as the lake water level was lowered from $740.7 \mathrm{~m}$ to $714.0 \mathrm{~m}$. (Fig. 8).

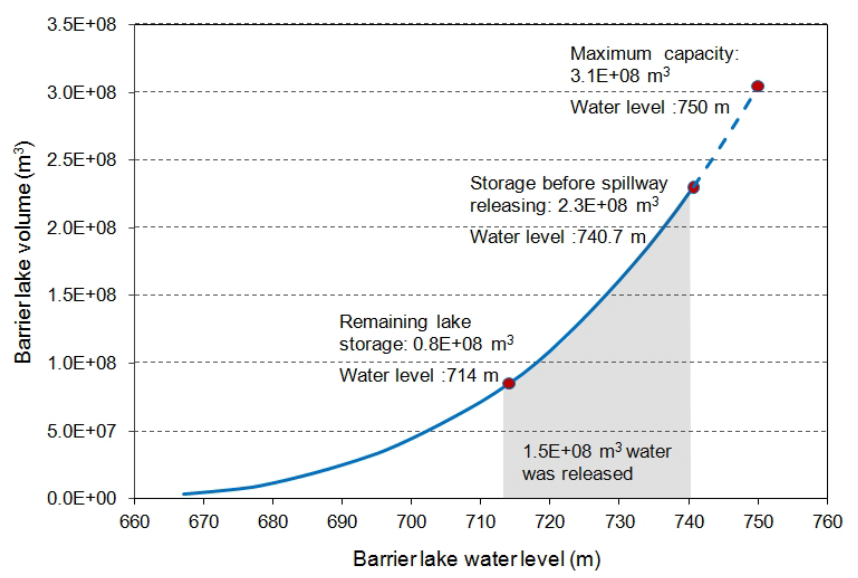

Fig. 8. Relationship between the volume and the water level of the barrier lake.

\subsection{The SOBEK 1-D-2-D model and data acquisition}

The SOBEK 1-D-2-D model was used to calculate the spatial and temporal variation in flood parameters (e.g. the flood area, depth, velocity, arrival time etc.), which is a graphically orientated model. This model combines the one-dimensional river flow and two-dimensional overland flow, switching from 1-D simulation of the flow in the river in the normal condition to 2-D when water overflows the channel and 


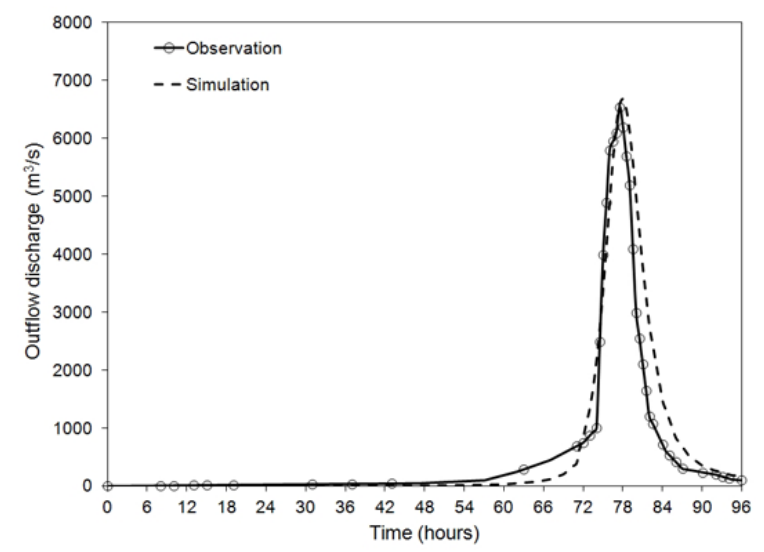

Fig. 9. Outflow hydrographs from the BREACH model and the observational data.

inundates areas along the river (see Dhondia and Stelling, 2002 for the background principles and the detailed hydrodynamic equations). It has been used for reconstructing a large-magnitude outburst flood from a glacial lake by Carrivick (2006).

To set up the model for the Tangjiashan dam-break flood simulation following data were collected:

- Field surveyed cross-sections and embankments of the Tongkou river channel: 35 cross-sections and $40 \mathrm{em}$ bankments were measured in the field by a handheld GPS and a laser distance meter (Fig. 1).

- The pre-earthquake Digital Elevation Model (DEM) with $25 \mathrm{~m}$ spatial resolution was generated from $1: 50000$ scale digital topographic maps by interpolating contour lines with intervals of $10 \mathrm{~m}$ and $20 \mathrm{~m}$ for low- and high-relief terrain, respectively (Fig. 1). The DEM was pre-processed before input into the model by filling the sinks and adding the embankments present at the time of the earthquake.

- The discharge and historical flood records of the Tongkou river were obtained from the Beichuan hydraulic stations and by reconstructing flood heights through field interviews (Table 1 and Fig. 1).

- The channel and floodplain roughness coefficients were estimated based on field observations and available land cover maps.

\section{Results}

\subsection{The BREACH model calibration and parameter sensitivity analysis}

The BREACH model was calibrated through reconstructing the 2008 event, by adjusting the geotechnical material
Table 3. The BREACH model calibration results. The peak duration represents the lasted time for the discharge being over $1000 \mathrm{~m}^{3} \mathrm{~s}^{-1}$; the peak appearing time is referred to the time from the first flow released through the spillway till the peak arrived; and the total released volume includes not only the lake volume but also the inflow volume during the breach.

\begin{tabular}{lrr}
\hline Output parameters & Simulation & Observation \\
\hline Peak discharge $\left(\mathrm{m}^{3} \mathrm{~s}^{-1}\right)$ & 6678 & 6540 \\
Total released-volume $\left(\mathrm{m}^{3}\right)$ & $1.94 \times 10^{8}$ & $1.86 \times 10^{8}$ \\
Peak duration (h) & 12 & 9 \\
Peak appearing time at the dam site (h) & 77.9 & 77.5 \\
Ultimate breach depth $(\mathrm{m})$ & 33.6 & 30.0 \\
Ultimate breach width $(\mathrm{m})$ & 77.6 & 100 \\
Ultimate breach bottom elevation $(\mathrm{m})$ & 706.4 & 710.0 \\
\hline
\end{tabular}

properties of the dam within the range of measured values, until the results were in correspondence with the observed hydrograph, showing a peak of $\sim 6500 \mathrm{~m}^{3} \mathrm{~s}^{-1}$ appearing around $77 \mathrm{~h}$ after the first flow out of the spillway on 7 June 2008 (Fig. 9 and Table 3). The breach channel predicted by the model was a bit deeper and narrower than the observations (Table 3).

A sensitivity analysis of dam material properties (Table 2) was carried out based on the Scenario 1. We found that the outflow hydrograph is more sensitive to the grain size, the unit weight and the porosity (Fig. 10a-c), while less sensitive to the internal friction angle and cohesion (see the supplementary material for the results). Larger grain size has little effect on the peak discharge, but postpones the peak arrival time obviously, as it controls the sediment transport rate (Fig. 10a). Lower values for the unit weight of the dam material lead to larger and faster outflow hydrograph peaks (Fig. 10b). The same effect is obtained by increasing the porosity (Fig. 10c).

\subsection{The BREACH model output uncertainty and results}

The uncertainties of the model outputs were analysed by using the extreme values from the range of the dam material properties of the dam, and using the Scenario 1. The peak discharge and time of the flood generated from the weakest combination were $\sim 10000 \mathrm{~m}^{3} \mathrm{~s}^{-1}$ higher and near $27 \mathrm{~h}$ earlier than those from the strongest case (Fig. 10d). The resulting variations of the flood 2-D simulation will be discussed in Sect. 4.3.

The BREACH model results demonstrate that the most catastrophic scenario (Scenario 4) produces the highest flood peak discharge of $\sim 75500 \mathrm{~m}^{3} \mathrm{~s}^{-1}$, but the shortest peak duration that lasted until the time the discharge reached $>1000 \mathrm{~m}^{3} \mathrm{~s}^{-1}$ (Fig. 11). The peak arrival time of the flood is the shortest for Scenario 3, due to the higher inflow rate, the lake would be filled up faster and the dam breach process would be accelerated. Compared to Scenario 1, in the base (calibrated) scenario the peak discharge decreases 

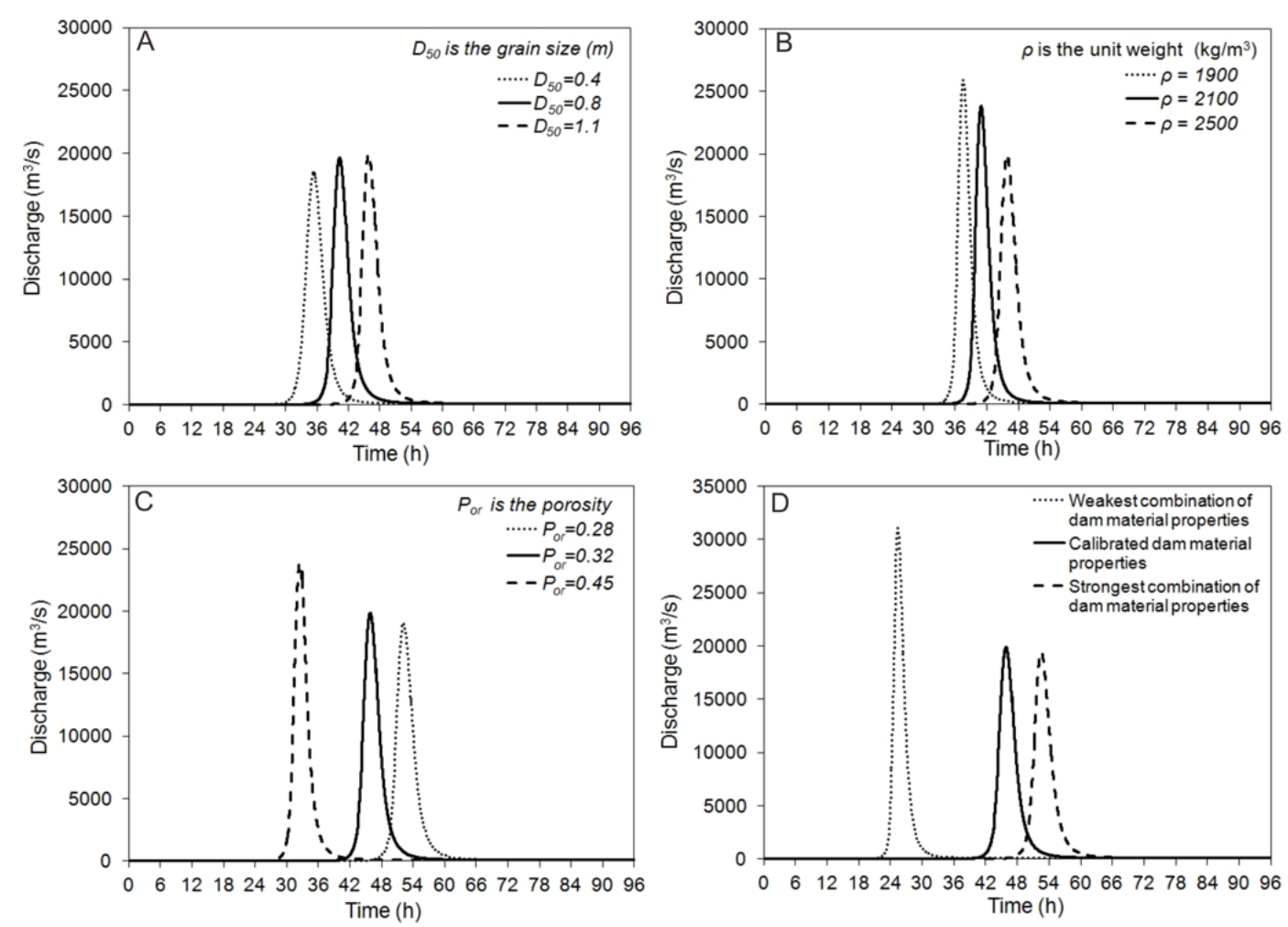

Fig. 10. Sensitivity analysis of the BREACH model outflow hydrograph to dam material properties (A: $D_{50}$ grain size; B: dam material unit weight; and $\mathbf{C}$ : porosity) and uncertainty analysis of the BREACH model outputs (D).

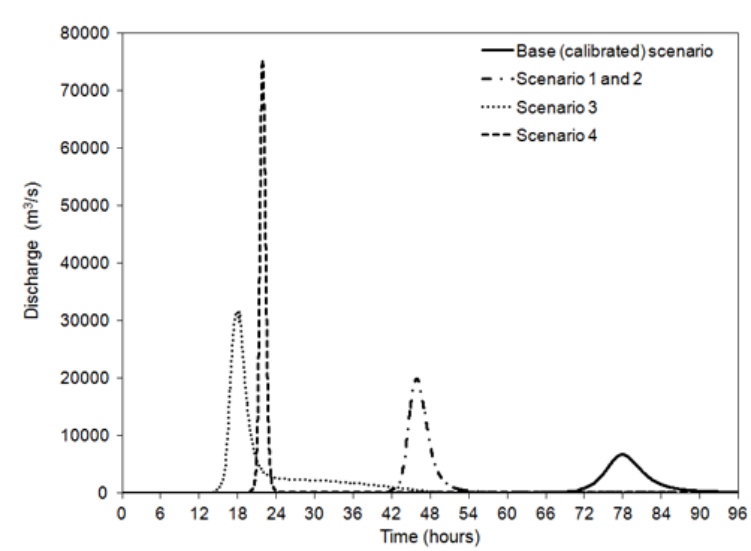

Fig. 11. Output hydrographs of the BREACH model.

significantly and the peak arrival time is delayed by nearly $32 \mathrm{~h}$, which proves that the spillway played a crucial role in reducing the dam-break outburst flood hazard. The difference of the Scenarios 1 and 2 is due to the cascading breach of the downstream dams, which can only be analysed in the SOBEK model.

\subsection{The SOBEK 1-D-2-D model results}

The SOBEK 1-D-2-D modelling was done with a special focus on the following issues:

\subsubsection{Cascading breach of four dams at the downstream of the Tangjiashan dam}

The Scenario 2 (cascading breach of downstream dams) (Figs. 1 and 4) is based on the assumption that these dams would fail by overtopping, which is supported by the previous conclusion that the majority of the landslide dams worldwide were documented to fail by overtopping (Costa and Schuster, 1988). The overtopping time of the downstream dams can be estimated by their geometry, the terrain and the outflow hydrograph of the Tangjiashan dam. Table 4 shows that their overtopping time is all a bit earlier than the peak arrival time at the Tangjiashan dam (45.9h, Fig. 11). They were estimated to be breaching during 44.2 to $45.3 \mathrm{~h}$ after the Tangjiashan dam was overtopped. Figure 12 demonstrates the cascading breach process of these dams.

\subsubsection{Simulation of flood hydrodynamics at the downstream towns}

We selected four measurement locations in the major towns and Mianyang city located downstream of the Tangjiashan 


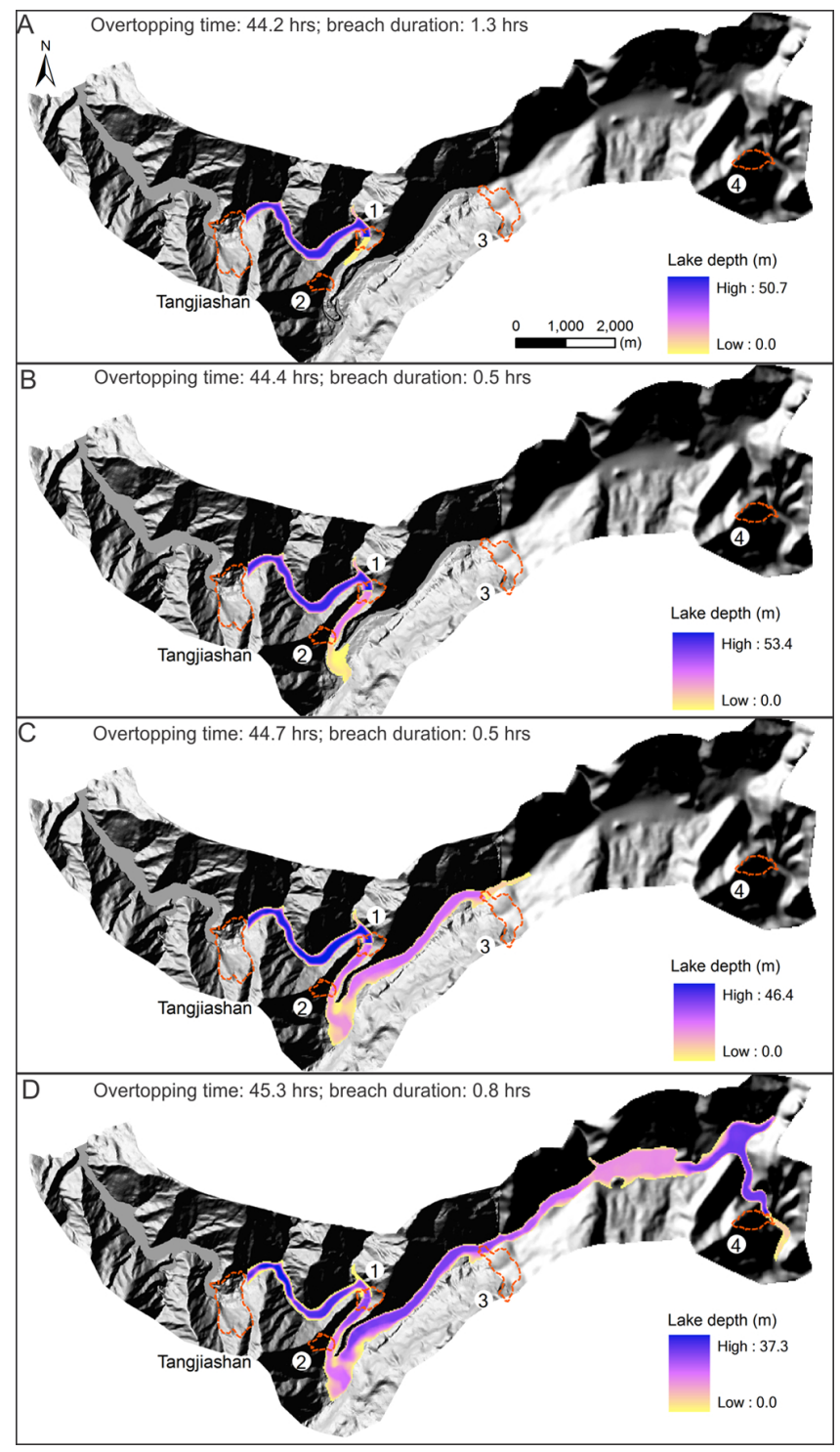

Fig. 12. Cascading breach of dam 1-4 (A-D) at the downstream part of the Tangjiashan dam.

dam to check the flood hydraulic parameters (Fig. 1). The result of the base scenario agrees well with the observational data (Table 5), which further verified that the BREACH model provided robust results and the SOBEK 1-D-2-D model results resemble reality. Figure 13 depicts the variation of the peak discharge and peak arrival time at these towns for different scenarios. In general, the peak discharge attenuates with an increase of the distance from the dam site. Flood control structures in Mianyang city were designed for a maximum discharge of $13000 \mathrm{~m}^{3} \mathrm{~s}^{-1}$, therefore all scenarios except the base scenario would cause flooding in the city (Fig. 13). Hence, the construction of the spillway did avoid serious flooding in Mianyang city. The Scenario 4 would generate a peak discharge which is almost five times larger
Table 4. Estimated failure time (by overtopping) of the downstream dams. The dam height and lake volume were reported by $\mathrm{Xu}$ et al. (2009), and are consistent with the calculation results by comparing the pre- and post- earthquake DEMs.

\begin{tabular}{lrrrr}
\hline $\begin{array}{r}\text { Number } \\
\begin{array}{r}\text { Dam height } \\
(\mathrm{m})\end{array}\end{array}$ & $\begin{array}{r}\text { Lake volume } \\
\left(\mathrm{m}^{3}\right)\end{array}$ & $\begin{array}{r}\text { Overtopping } \\
\text { time }(\mathrm{h})\end{array}$ & $\begin{array}{r}\text { Breach } \\
\text { duration }(\mathrm{h})\end{array}$ \\
\hline 1 & 60 & $2.0 \times 10^{6}$ & 44.2 & 1.3 \\
2 & 20 & $0.6 \times 10^{6}$ & 44.4 & 0.5 \\
3 & 20 & $0.8 \times 10^{6}$ & 44.7 & 0.5 \\
4 & 30 & $4.0 \times 10^{6}$ & 45.3 & 0.8 \\
\hline
\end{tabular}

and an arrival time that is $1.3 \mathrm{~h}$ earlier than the base scenario. The comparison of the Scenarios 1 and 2 indicates that the cascading breach of the downstream dams did not significantly increase the peak discharge and delay of the peak arrival time. This is because these dams were estimated to impound rather small amounts of water (in total, $7.4 \times 10^{6} \mathrm{~m}^{3}$ ), which is only $2 \%$ of the volume of the Tangjiashan lake (Fig. 13). The Tongkou town located nearest to the Tangjiashan dam downstream would be most influenced.

Figure 14 presents the flooded area, which occurs mainly on the floodplain, as the surrounding areas are substantial higher in elevation. The flooded area of Scenarios 1 and 2 are almost identical $\left(\sim 62 \mathrm{~km}^{2}\right)$ due to the limited effect of the cascading breaches of the downstream dams. Scenarios 3 and 4 may cause flooded areas of 70.5 and $78.7 \mathrm{~km}^{2}$, respectively, including most parts of Mianyang city. The spatial variation in flood parameters in different scenarios is presented in the Supplement.

\subsubsection{Variations of the 2-D flood simulation related to the SOBEK model input}

The variations of the 2-D flood simulation are highly related to the range of dam material properties. To assess these variations (uncertainties), we used as input in the SOBEK model the variations of BREACH model output hydrographs of both the weakest and strongest combinations of dam material properties shown in Fig. 10d. For Scenario 1 as an example, the resulting flooded area varies between $61 \mathrm{~km}^{2}$ (using the strongest dam properties) to $66 \mathrm{~km}^{2}$ (using the weakest ones). The maximum flood depth generated from the strongest combination is generally smaller than that from the weakest case (Fig. 15a and b). The difference between them at the downstream towns is less than $1 \mathrm{~m}$. In Mianyang city, the estimated variation of the flood depth is $3.09-3.65 \mathrm{~m}$. Figure $15 \mathrm{c}$ and $\mathrm{d}$ depict that the flood peak appearing time in the weakest case is about $27 \mathrm{~h}$ earlier than that in the strongest case, which is determined by the BREACH model output (Fig. 10d). The variability of the dam material properties causes a large uncertainty in the estimation of the peak arrival time, as it controls the dam breach speed and process. However, it has little influence on the flood inundation area 

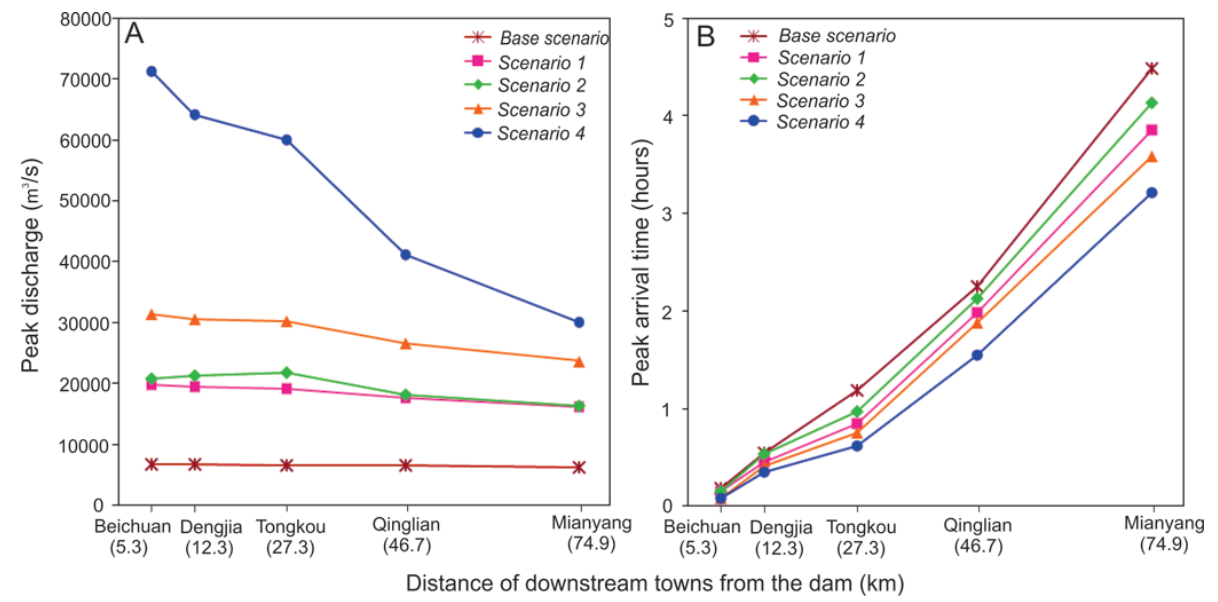

Fig. 13. Flood peak discharge (A) and peak arrival (B) passing through the towns located downstream of the Tangjiashan dam.

Table 5. The SOBEK simulation results of base scenario compared with observational data. The peak arrival time is referred to as the time lag between the peak appearing time at the Tangjiashan dam site and the time when it reaches the downstream towns.

\begin{tabular}{|c|c|c|c|c|c|c|}
\hline \multirow[t]{2}{*}{ Towns } & \multirow{2}{*}{$\begin{array}{r}\text { Distance from } \\
\text { dam }(\mathrm{km})\end{array}$} & \multicolumn{3}{|c|}{$\begin{array}{l}\text { SOBEK simulation } \\
\text { results }\end{array}$} & \multicolumn{2}{|c|}{ Observations } \\
\hline & & $\begin{array}{r}\text { Maximum } \\
\text { depth (m) }\end{array}$ & $\begin{array}{r}\text { Peak discharge } \\
\qquad\left(\mathrm{m}^{3} \mathrm{~s}^{-1}\right)\end{array}$ & $\begin{array}{r}\text { Peak arrival } \\
\text { time }(\mathrm{h})\end{array}$ & $\begin{array}{r}\text { Peak discharge } \\
\qquad\left(\mathrm{m}^{3} \mathrm{~s}^{-1}\right)\end{array}$ & $\begin{array}{r}\text { Peak arrival } \\
\text { time (h) }\end{array}$ \\
\hline Beichuan & 5.3 & 6.4 & 6665.3 & 0.18 & 6500 & 0.20 \\
\hline Dengjia & 12.3 & 11.7 & 6622.0 & 0.55 & - & - \\
\hline Tongkou & 27.3 & 18.3 & 6589.1 & 1.18 & 6300 & 1.25 \\
\hline Qinglian & 46.7 & 5.6 & 6481.0 & 2.25 & - & - \\
\hline Mianyang & 74.9 & 4.1 & 6281.4 & 4.48 & 6100 & 4.33 \\
\hline
\end{tabular}

and flood depth downstream, which are more determined by the lake volume. The time referred to here is from when the Tangjiashan dam was overtopped till the peak appeared at different locations. It can be converted to the relative time lag as shown in Table 5 and Fig. 13 by subtracting the peak appearing time at the Tangjiashan dam site (52.7 and $25.4 \mathrm{~h}$ for the strongest and weakest combinations, respectively; Fig. 10d). Thus, the time when it reaches Mianyang city after the peak appears at the dam site varies from 3.6 to $3.9 \mathrm{~h}$.

\section{Discussion}

After the sudden formation of a landslide dam, it is important to assess the dam stability and possible failure mode rapidly, to predict the dam-break flood magnitude, and to estimate the dam failure time and flood arrival time.

\subsection{Dam stability assessment}

The Tangjiashan landslide dam was considered unstable and might fail by overtopping (Cui et al., 2010; Fan et al., 2012a). The BREACH model was able to reconstruct the Tangjiashan event well. However, it cannot account for the heterogeneity of the dam composition materials. The existence of a thick layer of partly intact rock strata in the middle and bottom part of the dam were the main factors that prevented the dam to breach or collapse totally, except in extreme situations (e.g. heavy rainstorm, strong aftershocks). A sensitivity analysis of these parameters can help to quantify the uncertainty and diminish the effect of this limitation. Further improvement of the model is needed especially for inhomogeneous landslide dams, but this is beyond the scope of this study.

\subsection{Dam-break flood magnitude estimation}

The physically based and numerical models can provide more accurate results compared to the empirical method, but rely on more detailed dam and lake geometry data and geotechnical parameters of the dam materials. The predictions of peak discharge of the Tangjiashan dam from empirical equations proposed by previous studies in Table 6 are compared with those from the Scenario 4 of the BREACH model, as both of them consider the whole breach of the dam. These equations are based on either the lake volume $\left(V_{\mathrm{L}}\right)$ or on the potential energy $\left(P_{\mathrm{E}}\right)$, which is the product of dam height, lake volume, and specific weight of water. 


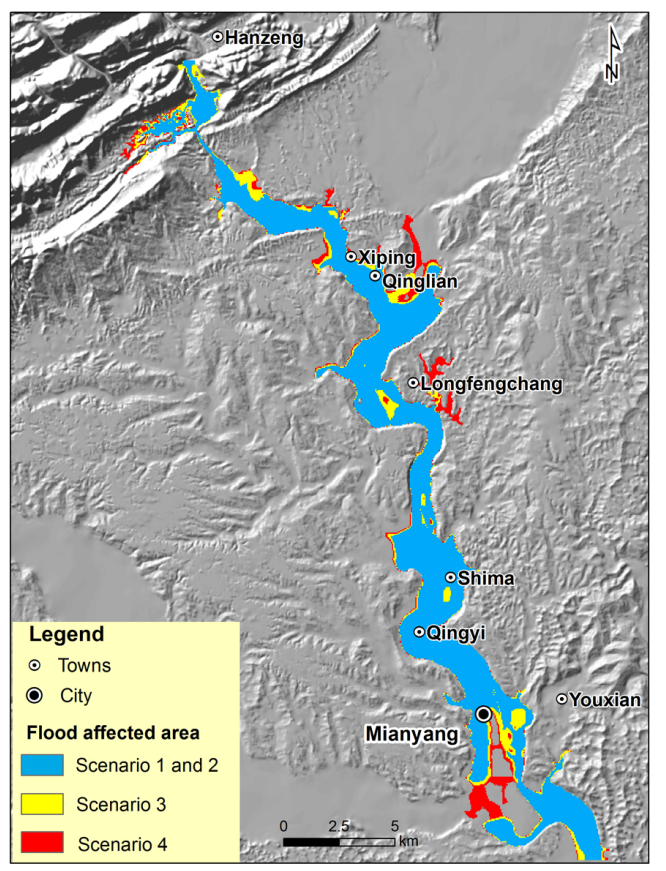

Fig. 14. Modelled flooded area for different scenarios. The yellow and red areas represent the increase in flooded area for Scenario 4 and 5 , respectively.

Table 6. Comparison of predictions of the peak discharge of the Tangjiashan landslide dam from empirical equations and the BREACH model.

\begin{tabular}{lll}
\hline $\begin{array}{l}\text { Empirical } \\
\text { equations }\end{array}$ & Reference & $\begin{array}{l}\text { Peak discharge } \\
\left(\mathrm{m}^{3} \mathrm{~s}^{-1}\right)\end{array}$ \\
\hline$Q_{\mathrm{p}}=0.72 V_{\mathrm{L}}^{0.53}$ & Evans (1986) & $2.28 \times 10^{4}$ \\
$Q_{\mathrm{p}}=1.6 V_{\mathrm{L}}^{0.46}$ & Walder and O'Connor (1997) & $1.29 \times 10^{4}$ \\
$Q_{\mathrm{p}}=3.4 V_{\mathrm{L}}^{0.46}$ & Cenderelli (2000) & $2.74 \times 10^{4}$ \\
$Q_{\mathrm{p}}=0.0158 P_{E}^{0.41}$ & Costa and Schuster (1988) & $1.28 \times 10^{4}$ \\
$Q_{\mathrm{p}}=0.063 P_{\mathrm{E}}^{0.42}$ & Clague and Evans (2000) & $7.08 \times 10^{4}$ \\
BREACH model & Fread (1991) & $7.55 \times 10^{4}$ \\
\hline
\end{tabular}

Note: $V_{\mathrm{L}}$ equals to $3.1 \times 10^{8} \mathrm{~m}^{3}$ for the Tangjiashan dam; and $P_{\mathrm{E}}$ is $2.55 \times 10^{14}$ joules, given the dam height of $84 \mathrm{~m}$ and the specific weight of water of $9800 \mathrm{~N} \mathrm{~m}^{-3}$.

The predicted peak discharge $\left(Q_{\mathrm{p}}\right)$ varies from $1.28 \times 10^{4}$ to $7.55 \times 10^{4} \mathrm{~m}^{3} \mathrm{~s}^{-1}$, with an average of $3.7 \times 10^{4} \mathrm{~m}^{3} \mathrm{~s}^{-1}$. The deviations of different empirical equations might result from site-specific characteristics of the original sample lakes in different study areas. The empirical equations underestimate the peak discharge compared to the results of the BREACH model. We consider the prediction from the BREACH model to be more reliable, as the model was calibrated by observational data (Fig. 9). In the Tangjiashan case, the equation proposed by Clague and Evans (2000) provides the closest prediction compared to the results of the BREACH model.
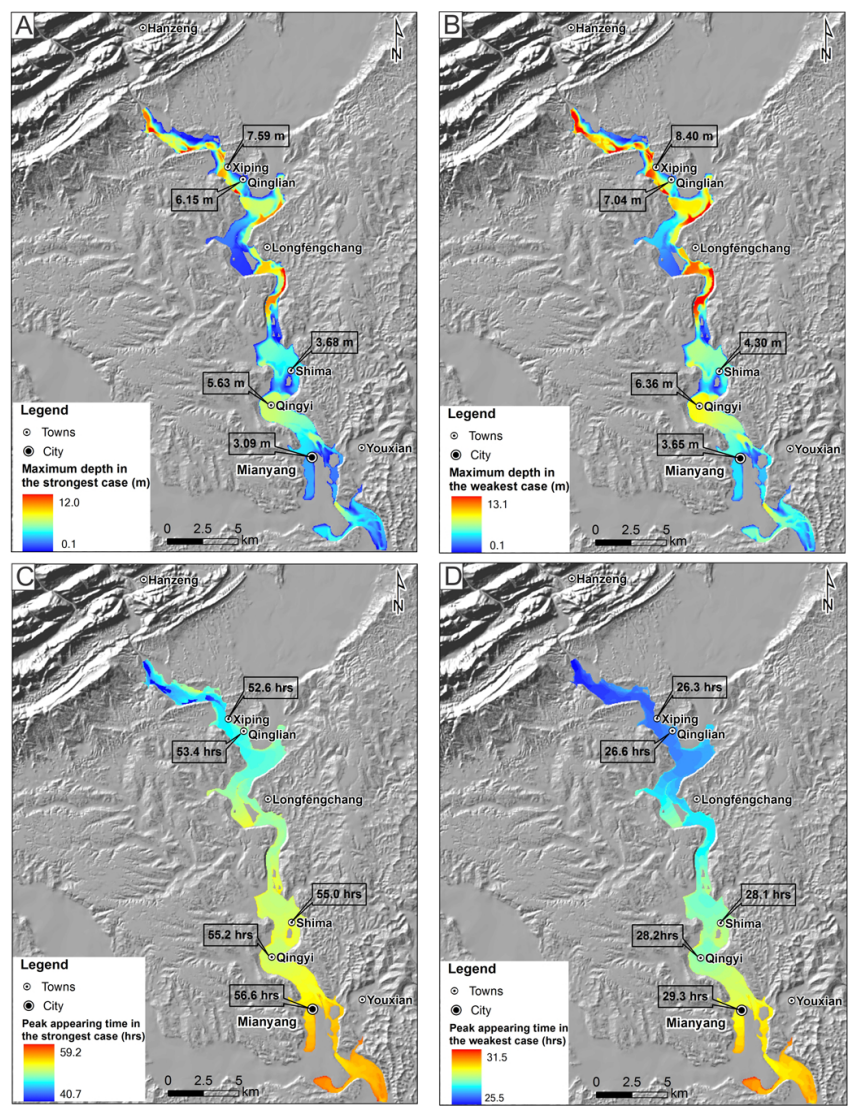

Fig. 15. Variation related to the inputs in the SOBEK model expressed as: the maximum flood depth generated from the strongest and weakest combinations of dam material properties (A and $\mathbf{B})$, and the peak appearing time in the strongest and weakest cases $(\mathbf{C}$ and D) based on the Scenario 1.

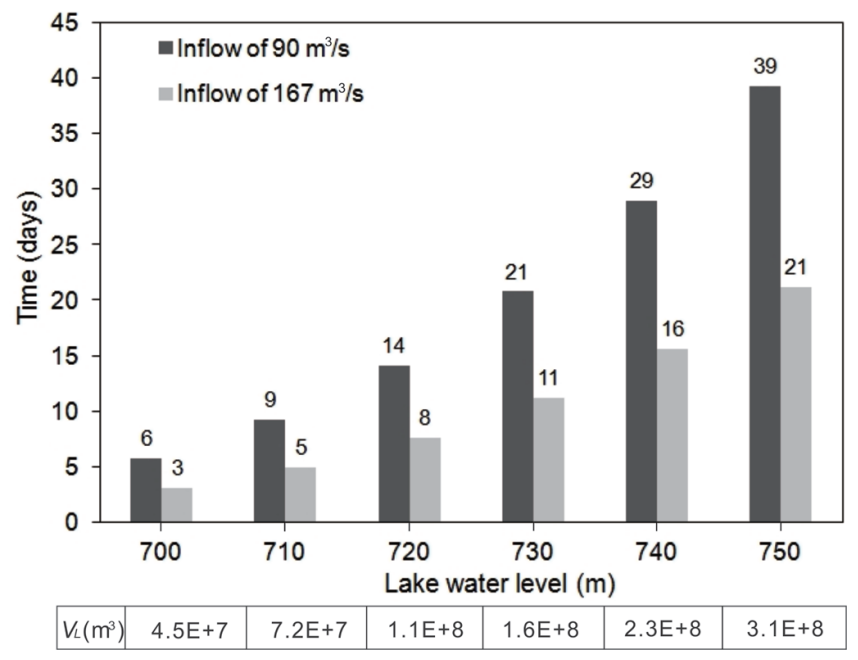

Fig. 16. Time needed for the barrier lake rising to a certain level and the lake volume $\left(V_{\mathrm{L}}\right)$. 
Table 7. Peak flood discharge and arrival time obtained from the SOBEK 1-D-2-D model and from the empirical Eqs. (1) and (2).

\begin{tabular}{lrrrrr}
\hline \multirow{2}{*}{$\begin{array}{l}\text { Locations } \\
\text { (towns) }\end{array}$} & $\begin{array}{r}\text { Distance from } \\
\text { dam }(\mathrm{km})\end{array}$ & \multicolumn{2}{c}{$\begin{array}{c}\text { SOBEK simulation } \\
\text { results Scenario } 1\end{array}$} & \multicolumn{2}{c}{$\begin{array}{c}\text { Results from } \\
\text { empirical equations }\end{array}$} \\
\cline { 3 - 6 } & & $\begin{array}{r}\text { Peak discharge } \\
\left(\mathrm{m}^{3} \mathrm{~s}^{-1}\right)\end{array}$ & $\begin{array}{r}\text { Peak arrival } \\
\text { time }(\mathrm{h})\end{array}$ & $\begin{array}{r}\text { Peak discharge } \\
\left(\mathrm{m}^{3} \mathrm{~s}^{-1}\right)\end{array}$ & $\begin{array}{r}\text { Peak arrival } \\
\text { time (h) }\end{array}$ \\
\hline Beichuan & 5.3 & $19752.3 \pm 6512.7$ & $0.15 \pm 0.04$ & $25028.3 \pm 974.0$ & $0.05 \pm 0.02$ \\
Dengjia & 12.3 & $19430.0 \pm 6280.5$ & $0.45 \pm 0.02$ & $22096.7 \pm 1732.0$ & $0.20 \pm 0.06$ \\
Tongkou & 27.3 & $19164.4 \pm 6193.3$ & $0.85 \pm 0.05$ & $17956.5 \pm 2505.9$ & $0.57 \pm 0.16$ \\
Qinglian & 46.7 & $17610.0 \pm 5082.8$ & $1.98 \pm 0.04$ & $14453.9 \pm 2766.3$ & $1.39 \pm 0.40$ \\
Mianyang & 74.9 & $16157.1 \pm 4226.9$ & $3.85 \pm 0.03$ & $11260.9 \pm 2698.0$ & $2.95 \pm 0.85$ \\
\hline
\end{tabular}

Note: the values in the table are mean \pm standard deviation. The range of the SOBEK simulation results is generated from the strongest and weakest combinations of dam material properties.

\subsection{Dam failure time and flood arrival time prediction}

The estimation of the dam failure time and flood arrival time is normally a race against the clock in an emergency situation. The prediction of dam overtopping (failure starting) time and peak arrival time at the downstream towns is crucial to determine the appropriate mitigation measures and available time for the engineering works or evacuation planning. The relation between the barrier lake volume and water level in Fig. 8 can be employed to predict the dam overtopping time for a given inflow rate. Using this method, we calculated the time needed for the lake to reach a certain level, given the measured-inflow in May $2008\left(90 \mathrm{~m}^{3} \mathrm{~s}^{-1}\right)$ and the average discharge of the Tongkou river in the monsoon season $\left(167 \mathrm{~m}^{3} \mathrm{~s}^{-1}\right)$ in Fig. 16. The time is referred to the number of days after the dam was formed, e.g. " 0 " represents 12 May 2008. The spillway was constructed when the lake level was $\sim 720 \mathrm{~m}$ and designed to be overtopped when the lake level reached $\sim 740 \mathrm{~m}$, so the maximum available time for construction was 15 days with a $90 \mathrm{~m}^{3} \mathrm{~s}^{-1}$ inflow rate, and would be shortened to 8 days with the inflow increasing to $167 \mathrm{~m}^{3} \mathrm{~s}^{-1}$. Our calculation was consistent with the reality that the spillway was overtopped on 7 June, 14 days after its construction on 26 May 2008.

The peak arrival time at the downstream towns was predicted by the SOBEK 1-D-2-D hydraulic model with the consideration of the terrain, channel and embankment features. Previous studies (Liu et al., 2009; Cui et al., 2010) have applied empirical equations to predict the flood peak discharge ( $Q_{\mathrm{PL}}$ in Eq. 1$)$ and the peak arrival time ( $t$ in the unit of second in Eq. 2) downstream from a landslide dam.

$Q_{\mathrm{PL}}=\frac{W}{\frac{w}{Q_{\mathrm{P}}}+\frac{L}{V K}}$

where $L$ is the distance from the dam (m); $W$ is the capacity of the lake $\left(\mathrm{m}^{3}\right) ; Q_{\mathrm{P}}$ is the peak discharge at the dam $\left(\mathrm{m}^{3} \mathrm{~s}^{-1}\right)$; and $V K$ is an empirical coefficient, equaling to 3.13 for rivers on plains, 7.15 for mountain rivers, and 4.76 for rivers flowing through the terrain with intermediate relief $(\mathrm{Li}$, 1980).

$t=k \frac{L^{1.4}}{W^{0.2} H_{0}^{0.5} h_{\mathrm{m}}^{0.25}}$

where $k$ is a coefficient, ranging from 0.8 to $1.2 ; H_{0}$ is the lake water level before dam failure (m); and $h_{\mathrm{m}}$ is the water level (m) at a control section when the peak discharge reaches (Hydrological manual of Sichuan Province, 1979).

We compared our SOBEK simulation results of Scenario 1 with the results of $50 \%$ dam failure scenario from the empirical Eqs. (1) and (2) obtained by Cui et al. (2010) in Table 7, as in Scenario 1 near half of dam material was estimated to be eroded. The empirical equations overestimated the peak discharge in the Beichuan and Dengjia towns, but underestimated it for the downstream towns and Mianyang city. The peak arrival time in the downstream towns was all overestimated, although they still can give a preliminary estimation, especially in the data scarcity and emergent situation.

\subsection{Discuss the design of the spillway}

The construction of the spillway played a significant role in preventing catastrophic flooding to the downstream towns and Mianyang city. However, in retrospect, there are lessons that can be learned for optimizing the design of the spillway and the excavation planning. For instance, the breach process was quite slow initially, with low discharge in the first three days after the breach (from 7 to 9 June), but suddenly accelerated on 10 June, reaching the peak of $\sim$ $6500 \mathrm{~m}^{3} \mathrm{~s}^{-1}$ just within $3 \mathrm{~h}$ (Fig. 9). This was faster than expected and increased the risk of catastrophic failure. Through the BREACH model parameter sensitivity analysis, we found that decreasing the channel gradient and material porosity of the coating of the channel bottom would have reduced the peak flood discharge and delayed the arrival time effectively. In addition, Cui et al. (2010) recommended that a compound cross-section combining a triangular configuration with that of a small trapezoid would have increased the low initial discharge. 


\section{Conclusions}

The Tangjiashan landslide dam was the most dangerous one of the approximately 800 coseismic landslide dams induced by the Wenchuan earthquake, and impounded the largest lake whose catastrophic outburst flooding threatened $\sim 2.5$ million people downstream. This research provided insights in the dam-breach process and the resulting flood propagation in possible scenarios. The integration of the BREACH model and the SOBEK model can provide predictions that agreed well with the observations. The uncertainty analysis revealed that the variability of the dam material properties will not significantly affect the flood inundation area and the maximum flood depth in the downstream area. However, it will cause large variation in the flood peak discharge and peak arrival time. We found that the cascading breach of the downstream dams did not have a major influence on the modelled flood parameters, because they had lake volumes much smaller than that of the Tangjiashan Lake. Based on the experience and lessons we learned from the simulations of the Tangjiashan event, we recommend making the mitigation measures on the basis of predictions from physically and hydraulically based models whenever possible. In data scarce situation, and in emergency situations with limited time to take decisions, the empirical method can also provide relatively good first-hand estimations.

\section{Supplementary material related to this article is available online at: \\ http://www.nat-hazards-earth-syst-sci.net/12/3031/2012/ nhess-12-3031-2012-supplement.pdf.}

Acknowledgements. This research was financially supported by the National Natural Science Foundation of the People's Republic of China (41130745) and the Creative Team Program of Ministry of Education of China (IRT0812), in collaboration with the United Nations University - ITC Centre for Spatial Analysis and Disaster Risk Management of the University of Twente, the Netherlands. The authors acknowledge the Mianyang Hydrological Center, Sichuan Hydrological and Water Resource Bureau and local municipalities for providing the hydrological and meteorological data. We thank Prof. Chuan Tang and Prof. Jing Zhu for their support to the fieldwork and data collection. We thank Alexander Strom, Theo van Asch and Jia-Jyun Dong for constructive comments on an earlier manuscript.

Edited by: B. D. Malamud

Reviewed by: A. Strom, J.-J. Dong, and T. Van Asch

\section{References}

Alexander, D.: Valtellina landslide and flood emergency, northern Italy, 1987, Disasters, 12, 212-222, 1988.

Carrivick, J. L.: Application of 2D hydrodynamic modeling to highmagnitude outburst floods: An example from Kverkfjöll, Iceland, J. Hydrol., 321, 187-199, 2006.

Casagli, N. and Ermini, L.: Geomorphic analysis of landslide dams in the Northern Apennine, Trans. Jpn. Geomorph. Union, 20, 219-249, 1999.

Cencetti, C., Fredduzzi, A., Marchesini, I., Naccini, M., and Tacconi, P.: Some considerations about the simulation of breach channel erosion on landslide dams, Computat. Geosci., 10, 201219, 2006.

Cenderelli, D. A.: Floods from natural and artificial dam failures, in: Inland Flood Hazards, edited by: Wohl, E. E., Cambridge University Press, New York, 73-103, 2000.

Chai, H., Liu, H., and Zhang, Z.: The catalog of Chinese landslide dam events, Journal of Geological Hazards and Environment Preservation, 6, 1-9, 1995 (in Chinese).

Chai, H., Liu, H., Zhang, Z., and Xu, Z.: The distribution, causes and effects of damming landslides in China, Journal of the Chengdu Institute of Technology, 27, 302-307, 2000 (In Chinese).

Chang, D. S. and Zhang, L. M.: Simulation of the erosion process of landslide dams due to overtopping considering variations in soil erodibility along depth, Nat. Hazards Earth Syst. Sci., 10, 933-946, doi:10.5194/nhess-10-933-2010, 2010.

Clague, J. J. and Evans, S. G.: Formation and failure of natural dams in the Canadian Cordillera, Geol. Surv. Canada Bull., 464, 1-35, 1994.

Clague, J. J. and Evans, S. G.: A review of catastrophic drainage of moraine-dammed lakes in British Columbia, Quaternary Sci. Rev., 19, 1763-1783, 2000.

Chengdu Hydroelectric Investigation and Design Institute (CHIDI) in China: Report on the stability assessment of the Tangjiashan landslide dam and up- and downstream slopes, 2008.

Costa, J. E. and Schuster, R. L.: The formation and failure of natural dams, Geol. Soc. Am. Bull., 100, 1054-1068, 1988.

Cruden, D. M. and Miller, B. G. N.: The Eureka River landslide and dam, Peace River Lowlands, Alberta. Can. Geotch. J., 39, 863-878, 2002.

Cui, P., Dang, C., Zhuang, J., You, Y., Chen, X., and Scott, K. M.: Landslide-dammed lake at Tangjiashan, Sichuan Province, China (triggered by the Wenchuan earthquake, 12 May, 2008): risk assessment, mitigation strategy, and lessons learned, Environ. Earth Sci., 65, 1055-1065, 2012.

Dai, F., Lee, C., Deng, J., and Tham, L. G.: The 1786 earthquaketriggered landslide dam and subsequent dam-break flood on the Dadu River, southwestern China, Geomorphology, 65, 205-221, 2005.

Dai, J., Zhang, S., and Xue, C.: Dam-break flood modeling for Tangjiashan Quake Lake, Second International Conference on Earth Observation for Global Changes. Proc. SPIE Vol. 7471, 74711D, doi:10.1117/12.836313, 2010.

Dhondia, J. F. and Stelling, G. S.: Application of the one dimensional-two dimensional integrated hydraulic model for flood simulation and damage assessment, Hydroinformatics 2002: Proceedings of the Fifth International Conference on Hydroinformatics, Cardiff, UK, 2002. 
Dong, J. J, Tung, Y. H., Chen, C. C., Liao, J. J., and Pan, Y. W.: Discriminant analysis of the geomorphic characteristics and stability of landslide dams, Geomorphology, 110, 162-171, 2009.

Duman, T. Y.: The largest landslide dam in Turkey: Tortum landslide, Eng. Geol., 104, 66-79, 2009.

Dunning, S. A., Rosser, N. J., Petley, D. N., and Massey, C. R.: Formation and failure of the Tsatichhu landslide dam, Bhutan, Landslides, 3, 107-113, 2006.

Ermini, L. and Casagli, N.: Prediction of the behavior of landslide dams using a geomorphological dimensionless index, Earth Surf. Proc. Landf., 28, 31-47, 2003.

Evans, S. G.: The maximum discharge of outburst floods caused by the breaching of man-made and natural dams, Can. Geotch. J., 23, 385-87, 1986.

Evans, S. G., Delaney, K. B., Hermanns, R. L., Strom, A., and Scarascia-Mugnozza, G.: The formation and behaviour of natural and artificial rockslide dams; implications for engineering performance and hazard management, in: Natural and artificial rockslide dams, edited by: Evans, S. G., Hermanns, R. L., Strom, A. L., Scarascia-Mugnozza, G., and Mugnozza, G., Berlin: Springer, Lecture Series in Earth Sciences, 1-76, 2011.

Fan, X., van Westen, C. J., Korup, O., Gorum, T., Xu, Q., Dai, F., Huang, R., and Wang, G.: Transient water and sediment storage of the decaying landslide dams induced by the 2008 Wenchuan Earthquake, China, Geomorphology, 171-172, 58-68, 2012.

Fan, X., van Westen, C. J., Xu, Q., Gorum, T., and Dai, F.: Analysis of landslide dams induced by the 2008 Wenchuan earthquake, J. Asian Earth Sci., 57, 25-37, 2012.

Fread, D. L.: BREACH: an erosion model for earth dam failures. Hydrologic Research Laboratory, US National Weather Service, 1991.

Gupta, V. and Sah, M. P.: Impact of the Trans-Himalayan Landslide Lake Outburst Flood (LLOF) in the Satluj catchment, Himachal Pradesh, India, Nat. Hazards, 45, 379-390, 2008.

Hewitt, K.: Catastrophic landslides and their effects on the Upper Indus streams, Karakoram Himalaya, northern Pakistan, Geomorphology, 26, 47-80, 1998.

Hydrological manual of Sichuan Province, Hydrology office of Sichuan Province, Sichuan Science and Technique House, Chengdu, 1979 (in Chinese).

Korup, O.: Recent research on landslide dams-a literature review with special attention to New Zealand, Prog. Phys. Geog., 26, 206-235, 2002.

Korup, O.: Geomorphic hazard assessment of landslide dams in South Westland, New Zealand: Fundamental problems and approaches, Geomorphology, 66, 167-188, 2005.
Li, M. H., Sung, R. T., Dong, J. J., Lee, C. T., and Chen, C. C.: The formation and breaching of a short-lived landslide dam at Hsiaolin Village, Taiwan-Part II: Simulation of debris flow with landslide dam breach, Eng. Geol., 123, 60-71, 2011.

Li, W.: Handbook of hydraulic calculations, Water Publication, Beijing, 1980 (in Chinese).

Liu, N., Zhang, J., Lin, W., Cheng, W., and Chen, Z.: Draining Tangjiashan Barrier Lake after Wenchuan Earthquake and the flood propagation after the dam break, Sci. China Ser. E., 52, 801-809, 2009.

Mason, K.: Indus floods and Shyok glaciers, Himalayan J., 1, 1029, 1929.

O'Connor, J. E. and Costa, J. E.: The world's largest floods, past and present - Their causes and magnitudes, US Geological Survey Circular, 1254, 1-13, 2004.

Peng, M. and Zhang, L. M.: Breaching parameters of landslide dams, Landslides, 9, 13-31, 2012.

Schneider, J. F.: Seismically reactivated Hattian slide in Kashmir, Northern Pakistan, J. Seismol., 13, 387-398, 2009.

Shang, Y., Yang, Z., Li, L., Liu, D., Liao, Q., and Wang, Y.: A superlarge landslide in Tibet in 2000: background, occurrence, disaster, and origin, Geomorphology, 54, 225-243, 2003.

Shroder Jr., J. F.: Slope failure and denudation in the western Himalaya, Geomorphology, 26, 81-105, 1998.

Smart, G. M.: Sediment transport formula for steep channels, J. Hydraul. Divisions - ASCE 110, 267-276, 1984.

Swanson, F. J., Oyagi, N., and Tominaga, M.: Landslide dams in Japan, in: Landslide dams: process, risk, and mitigation New York: American Society of Civil Engineers Special Publication, edited by: Schuster, R. L., No. 3, 273-378, 1986.

Walder, J. S. and O'Connor, J. E.: Methods for predicting peak discharge of floods caused by failure of natural and constructed earthen dams, Water Resour. Res., 33, 2337-48, 1997.

Wang, G., Liu, F., Fu, X., and Li, T.: Simulation of dam breach development for emergency treatment of the Tangjiashan Quake lake in China, Sci. China Ser. E., 51, Supp. II, 82-94, 2008.

Xu, Q., Fan, X., Huang, R., and van Westen, C. J.: Landslide dams triggered by the Wenchuan earthquake, Sichuan Province, south west China, Bull. Eng. Geol. Environ., 68, 373-386, 2009.

Xu, Q., Shang, Y., van Asch, T., Wang, S., Zhang, Z., and Dong, $\mathrm{X}$.: Observations from the large, rapid Yigong rock slide-debris avalanche, southeast Tibet, Can. Geotech. J., 49, 589-606, 2012. 